\title{
Formulasi Kebijakan Roadmap Inovasi Daerah di Kabupaten Bekasi
}

\author{
Waluyo Zulfikar' ${ }^{1}$, Ipah Ema Jumiati ${ }^{2}$ \\ ${ }^{1}$ Program Sarjana Administrasi Publik Universitas Nurtanio Bandung, Indonesia; \\ ${ }^{2}$ Magister Administrasi Publik Universitas Sultan Ageng Tirtayasa Serang, Indonesia;
}

\begin{abstract}
Bekasi Regency is the area with the largest industrial area in Southeast Asia, where there are 16 industrial areas with relatively large land area. In addition, there are also seven large industrial zones or industrial zones on an international scale, in line with this, the problem of public service delivery in the Bekasi District Government must be carried out properly to the public. In optimizing the public services, various innovative ideas and ideas are needed to create synergy and efficiency in the provision of these public services. In this study, the innovation system is a unified component that influences the direction of development and speed of innovation, diffusion, and learning processes in the development, mastery, advancement and application/utilization of science and technology. How sub-subsystems (elements / factors) play their roles, their interrelations (including policy coherence), and the dynamics of their interactions determine or influence the dynamic performance of innovation systems. Strengthening the innovation system means structuring the system (holistic, simultaneous, systemic issues) in a structured way. In a policy perspective, strengthening innovation systems means remedial steps that need to be directed to address systemic failures. Therefore, policy strategies need to be developed as a unified innovation policy framework (KKI) to strengthen the system.
\end{abstract}

Keywords: Regional Innovation, SIDA, Bekasi Regency

\begin{abstract}
Abstrak
Kabupaten Bekasi merupakan daerah dengan kawasan industri terbesar di Asia Tenggara, dimana terdapat 16 kawasan industri dengan luasan lahan yang relatif besar. Selain itu, terdapat pula tujuh zona atau kawasan industri besar berskala internasional, sejalan dengan hal tersebut, permasalahan penyelenggaraan pelayanan publik di Pemerintah Daerah Kabupaten Bekasi harus diselenggarakan secara baik kepada masyarakat. Di dalam optimalisasi dalam pelayanan publik tersebut, maka berbagai ide dan gagasan inovatif daerah sangat diperlukan untuk menciptakan sinergi dan efisiensi dalam penyediaan pelayanan publik tersebut. Dalam penelitian ini, sistem inovasi merupakan suatu kesatuan komponen yang mempengaruhi arah perkembangan dan kecepatan inovasi, difusi, dan proses pembelajaran dalam pengembangan, penguasaan, pemajuan dan penerapan/ pemanfaatan iptek. Bagaimana sub-subsistem (elemen/ faktor) berperan, kesaling-terkaitannya (termasuk koherensi kebijakannya), dan dinamika interaksinya menentukan atau mempengaruhi kinerja dinamis sistem inovasi. Penguatan sistem inovasi berarti membenahi sistem (holistik, serentak, isu-isu sistemik) secara terstruktur. Dalam perspektif kebijakan, penguatan sistem inovasi berarti langkah perbaikan yang perlu diarahkan untuk membenahi isu-isu kegagalan sistemik (systemic failures). Oleh karena itu, strategi kebijakan perlu dikembangkan sebagai suatu kesatuan kerangka kebijakan inovasi (KKI) untuk memperkuat sistem.
\end{abstract}

Kata kunci: Inovasi Daerah, SIDA, Kabupaten Bekasi 
${ }^{*}$ Penulis Korespondensi

E-mail : ipah.ema@untirta.ac.id

\section{PENDAHULUAN}

Penyelenggaraan tata kelola pemerintahan yang baik (good governance) yang mulai banyak dilakukan oleh daerah-daerah saat ini tidak terlepas dari peluang yang diberikan oleh Undang-Undang Otonomi Daerah. Prinsip-prinsip good governance yaitu transparansi, partisipasi, efisiensi dan efektivitas, akuntabilitas, keterbukaan, tatanan hukum yang baik (rule of law), ketanggapan, equity, dan visi strategis merupakan prinsip-prinsip yang harus dicapai dalam pelaksanaan good governance. Dari beberapa daerah yang telah lebih dahulu melaksanakan praktek-praktek tata kelola pemerintahan yang baik diperoleh hasil bahwa praktek-praktek good governance yang dilaksanakan secara nyata mampu menciptakan sistem pemerintahan yang lebih bersih dan akuntabel, sistem pelayanan kepada masyarakat yang lebih baik dan bahkan di beberapa daerah mampu meningkatkan kesejahteraan pegawai.

Pelaksanaan otonomi daerah di Indonesia yang didasarkan pada UU No. 22 Tahun 1999 yang telah diubah menjadi UU No. 32 Tahun 2004 tentang Pemerintahan Daerah, pada tahun 2014 telah disempurnakan menjadi UU No. 23 Tahun 2014 dan disempurnakan kembali dengan UU No. 9 Tahun 2015. Hal ini merupakan landasan bagi pemerintah daerah dalam menjalankan roda pemerintahan di seluruh wilayah nusantara. Otonomi Daerah menciptakan ruang gerak yang lebih bebas dalam membuat kebijakan dan peraturan daerah yang melibatkan pihak-pihak terkait yang sesuai dengan pemahaman dan kebutuhan masyarakat masing-masing daerah tersebut. Dengan otonomi daerah diharapkan terjadi peningkatan pelayanan publik sekaligus memperbaiki kesejahteraan hidup masyarakat.

Terkait tata kelola pemerintahan di daerah, Kabupaten Bekasi merupakan salah satu Kabupaten yang berdekatan dengan Ibukota Jakarta sebagai pusat pemerintahan nasional. Memiliki batas wilayah sebelah barat berbatasan langsung dengan Daerah Khusus Ibukota Jakarta dan Kota Bekasi, di wilayah utara berbatasan dengan laut Jawa, sebelah selatan berbatasan dengan kabupaten Bogor, sedangkan di wilayah Timur perbatasan Kabupaten bekasi adalah dengan Kabupaten Karawang.

Kabupaten Bekasi memiliki letak geografis pada posisi 1060 48' 28" - 1070 27' 29" Bujur Timur dan 050 54' 50" - 060 29' 15" Lintang Selatan.Topografinya terbagi atas dua bagian yaitu dataran rendah yang meliputi sebagian wilayah bagian utara dan dataran bergelombang di wilayah bagian selatan, ketinggian lokasi terletak diantara 6-115 meter dan kemiringan 0-250 meter. Kabupaten Bekasi sebagai salah satu kabupaten bagian dari wilayah Provinsi Jawa Barat, secara administratif terdiri dari 23 Kecamatan, 5 Kelurahan dan 182 desadengan luas wilayah $127.388 \mathrm{Ha}$ atau sebesar $3,43 \%$ persen dari luas Provinsi Jawa Barat yang memiliki luas daratan 3.710.061,32 ha.

Kabupaten bekasi tersebut terbagi atas beberapa kecamatan yaitu 
terdapat 23 kecamatan dan 187 desa/kelurahan (5 kelurahan). Berdasarkan Peraturan Daerah Nomor 3 Tahun 2010 tentang Perubahan Status Desa Menjadi Kelurahan, dari 187 desa secara bertahap telah berubah menjadi kelurahan. Perkembangan terakhir terdapat 7 desa yang ditingkatkan statusnya menjadi kelurahan. Hal ini terjadi sebagai upaya untuk meningkatkan pelayanan masyarakat dan untuk mempercepat terwujudnya kesejahteraan masyarakat. Jumlah desa di setiap kecamatan berkisar antara 6 sampai 13 desa. Kecamatan dengan jumlah desa yang paling sedikit yaitu kecamatan Cikarang Pusat, Bojongmangu dan Muaragembong masing-masing sebanyak 6 desa, sedangkan kecamatan yang memiliki jumlah desa terbanyak adalah Kecamatan Pebayuran yaitu 13 desa. Kecamatan terluas adalah Muaragembong (14.009 $\mathrm{Ha}$ ) atau 11,00 \% dari luas kabupaten.

Kabupaten Bekasi merupakan daerah dengan kawasan industri terbesar di Asia Tenggara, dimana terdapat 16 kawasan industri dengan luasan lahan yang relatif besar. Selain itu, terdapat pula tujuh zona atau kawasan industri besar berskala internasional, sejalan dengan hal tersebut, permasalahan penyelenggaraan pelayanan publik di Pemerintah Daerah Kabupaten Bekasi harus diselenggarakan secara baik kepada masyarakat. Karena itu sebagai ujung tombak penyelenggaraan otonomi daerah pemerintah yang mampu menciptakan kesejahteraan di tingkat lokal sehingga memperkuat kepada kesejahteraan masyarakat secara nasional. Kesejahteraan masyarakat terkait dengan kualitas dan kuantitas pelayanan publik. Penyediaan pelayanan publik untuk masyarakat sangat terkait dengan urusan pemerintahan yang menjadi kewenangan suatu daerah. Di dalam optimalisasi dalam pelayanan publik tersebut, maka berbagai ide dan gagasan inovatif daerah sangat diperlukan untuk menciptakan sinergi dan efisiensi dalam penyediaan pelayanan publik tersebut.

Sistem inovasi merupakan suatu kesatuan komponen yang mempengaruhi arah perkembangan dan kecepatan inovasi, difusi, dan proses pembelajaran dalam pengembangan, penguasaan, pemajuan dan penerapan/ pemanfaatan iptek. Bagaimana subsubsistem (elemen/ faktor) berperan, kesaling-terkaitannya (termasuk koherensi kebijakannya), dan dinamika interaksinya menentukan atau mempengaruhi kinerja dinamis sistem inovasi. Penguatan sistem inovasi berarti membenahi sistem (holistik, serentak, isu-isu sistemik) secara terstruktur. Dalam perspektif kebijakan, penguatan sistem inovasi berarti langkah perbaikan yang perlu diarahkan untuk membenahi isu-isu kegagalan sistemik (systemic failures). Oleh karena itu, strategi kebijakan perlu dikembangkan sebagai suatu kesatuan kerangka kebijakan inovasi (KKI) untuk memperkuat sistem (Taufik, 2012 dalam Kuncoro B. Prayitno, dkk. 2014:73).

Menurut Peraturan Bersama Menteri Negara Riset Dan Tekonologi Republik Indonesia dan Menteri Dalam Negeri Republik Indonesia Nomor 03 Tahun 2012 dan Nomor 36 Tahun 2012 Tentang Penguatan Sistem Inovasi Daerah, pada Pasal 1 ayat 2 berbunyi Sistem Inovasi Daerah yang selanjutnya disingkat SIDa bahwa: "keseluruhan proses dalam satu sistem untuk menumbuhkembangkan inovasi yang dilakukan antar institusi pemerintah, pemerintah daerah, lembaga kelitbangan, lembaga pendidikan, lembaga penunjang 
inovasi, dunia usaha, dan masyarakat di daerah."

Maka, jika inovasi dilakukan akan muncul beberapa indikator perubahan. Menurut Solow (1956), inovasi akan melahirkan peningkatan kapital dan jumlah, kualitas maupun produktivitas tenaga kerja. Pertumbuhan temuan dan hasil inovasi (Nadiri, 1993; Griliches, 1990) akan meningkat. Hal ini karena perubahan teknologi akan merangsang masyarakat untuk memaksimalkan pertumbuhan produktifitasnya, misalnya dengan inovasi teknologi, laba dan substitusi teknologi. Sehingga perilaku kompetitif akan semakin meningkat akibat meningkatnya motif berinovasi (Romer, 1990; Kirzner, 1973). Maka dengan semakin berkembangnya Iptek, akan muncul usaha-usaha baru dan pemainpemain baru yang akan meningkatkan pertumbuhan ekonomi dan daya saing daerah.

Di dalam pasal 4 Berdasarkan Peraturan Pemerintah Republik Indonesia Nomor 38 Tahun 2017 Tentang Inovasi Daerah, disebutkan bahwa bentuk inovasi daerah mencakup a. inovasi tata kelola Pemerintahan Daerah; dan b. inovasi Pelayanan Publik; dan/atau Inovasi Daerah lainnya sesuai dengan Urusan Pemerintahan yang menjadi kewenangan Daerah. Inovasi Daerah lainnya sebagaimana dimaksud tersebut merupakan segala bentuk inovasi dalam penyelenggaraan Urusan Pemerintahan yang menjadi kewenangan Pemerintah Daerah.

Urgensi sistem inovasi daerah diperkuat melalui berbagai instrumen kebijakan pemerintah. Berbagai Peraturan perundang-undangan ditetapkan untuk selanjutnya dapat terimplementasi dalam pembangunan di daerah. Salah satu Peraturan Presiden yang dikeluarkan secara khusus terkait inovasi daerah adalah
Peraturan Pemerintah Republik Indonesia Nomor 38 Tahun 2017 Tentang Inovasi Daerah (Tambahan Lembaran Negara Republik Indonesia Nomor 6123). Hal ini sangat beralasan karena dalam tata kelola pemerintahan di era otonomi daerah sudah disebutkan dalam Undangundang diantaranya Undang-Undang Republik Indonesia Nomor 18 Tahun 2002 tentang Sistem Nasional Penelitian, Pengembangan, dan Penerapan Ilmu Pengetahuan dan Teknologi (Tambahan Lembaran Negara Republik Indonesia Nomor 4219); serta dalam Undang-undang Nomor 23 Tahun 2014 tentang Pemerintahan Daerah (Lembaran Negara Republik Indonesia Tahun 2014 Nomor 244);

Ditinjau dari aspek yuridis, inovasi daerah diatur melalui perundang-undangan terkait terdisri dari berbagai Undang-undang yaitu: Undang-Undang Republik Indonesia Nomor 18 Tahun 2002 tentang Sistem Nasional Penelitian, Pengembangan, dan Penerapan Ilmu Pengetahuan dan Teknologi (Tambahan Lembaran Negara Republik Indonesia Nomor 4219); Undang-Undang Nomor 17 Tahun 2003 tentang Keuangan Negara (Lembaran Negara Tahun 2003 Nomor 47 (Tambahan Lembaran Negara Republik Indonesia Nomor4287); Undang-Undang Nomor 1 Tahun 2004 tentang Perbendaharaan Negera (Lembaran Negara Tahun 2005 Nomor 5, Tambahan Lembaran Negara Republik Indonesia Nomor 4355); Undang-Undang Nomor 25 Tahun 2004 tentang Sistem Perencanaan Pembangunan Nasional (Lembaran Negara Tahun 2004 Nomor 104 Tambahan Lembaran Negara Republik Indonesia Nomor 4421); UndangUndang Republik Indonesia Nomor 17 Tahun 2007 Tentang Rencana Pembangunan Jangka Panjang Nasional Tahun 2005-2025 
(Tambahan Lembaran Negara Republik Indonesia Nomor 4700); Undang-Undang Republik Indonesia Nomor 14 Tahun 2008 Tentang Keterbukaan Informasi Publik (Lembaran Negara Republik Indonesia Tahun 2008 Nomor 61, Tambahan Lembaran Negara Republik Indonesia 4846); Undang-Undang Republik Indonesia Nomor 39 Tahun 2008 Tentang Kementerian Negara (Tambahan Lembaran Negara Republik Indonesia Nomor 4916); Undang-Undang Nomor 25 Tahun 2009 Tentang Pelayanan Publik (Lembaran Negara Republik Indonesia Tahun 2009 Nomor 112, Tambahan Lembaran Negara Republik Indonesia Nomor 5038); Undang-Undang Nomor 12 Tahun 2011 tentang Pembentukan Peraturan Perundang-undangan (Lembaran Negara Republik Indonesia Tahun 2011 Nomor 82, Tambahan Lembaran Negara Republik Indonesia Nomor 5234); Undang-undang Nomor 23 Tahun 2014 tentang Pemerintahan Daerah (Lembaran Negara Republik Indonesia Tahun 2014 Nomor 244); Undang-Undang Republik Indonesia Nomor 2 Tahun 2015 Tentang Penetapan Peraturan Pemerintah Pengganti Undang-Undang Nomor 2 Tahun 2014 Tentang Perubahan Atas Undang-Undang Nomor 23 Tahun 2014 Tentang Pemerintahan Daerah Menjadi Undang-Undang (Tambahan Lembaran Negara Republik Indonesia Nomor 5657); Undang-Undang Republik Indonesia Nomor 9 Tahun 2015 Tentang Perubahan Kedua Atas Undang-Undang Nomor 23 Tahun 2014 Tentang Pemerintahan Daerah (Lembaran Negara Republik Indonesia Tahun 2015 Nomor 58).

Peraturan terkait inovasi dalam peraturan pemerintah dan peraturan perundang-undangan di bawahnya yaitu terdiri atas: Peraturan Pemerintah Nomor 20 Tahun 2005 tentang Alih Teknologi Kekayaan
Intelektual Serta Hasil Penelitian dan Pengembangan oleh Perguruan Tinggi dan Lembaga Penelitian dan Pengembangan (Lembaran Negara Republik Indonesia Tahun 2005 Nomor 43, Tambahan Lembaran Negara Republik Indonesia Nomor 4497); Peraturan Pemerintah Republik Indonesia Nomor 38 Tahun 2007 Tentang Pembagian Urusan Pemerintahan Antara Pemerintah, Pemerintahan Daerah Provinsi, Dan Pemerintahan Daerah Kabupaten/Kota (Lembaran Negara Republik Indonesia Tahun 2007 Nomor 82); Peraturan Pemerintah Republik Indonesia Nomor 96 Tahun 2012 tentang Pelaksanaan UndangUndang Nomor 25 Tahun 2009 tentang Pelayanan Publik (Lembaran Negara Republik Indonesia Tahun 2012 Nomor 215, Tambahan Lembaran Negara Republik Indonesia Nomor 5357); Peraturan Pemerintah Republik Indonesia Nomor 38 Tahun 2017 Tentang Inovasi Daerah (Tambahan Lembaran Negara Republik Indonesia Nomor 6123); Peraturan Pemerimah Republik Indonesia Nomor 28 Tahun 2018 Tentang Kerja Sama Daerah (Lembaran Negara Republik Indonesia Tahun 2018 Nomor 97); Peraturan Presiden Nomor 32 Tahun 2010 tentang Komite Inovasi Nasional; Peraturan Presiden Nomor 42 Tahun 2014 tentang Perubahan Atas Peraturan Presiden Nomor 32 Tahun 2010 Tentang Komite Inovasi Nasional; Peraturan Menteri Dalam Negeri Nomor 20 Tahun 2011 tentang Pedoman Penelitian dan Pengembangan di lingkungan Kementerian Dalam Negeri dan Pemerintahan Daerah; Peraturan Bersama Menristek dan Mendagri Nomor 03 Tahun 2012 dan Nomor 36 Tahun 2012 tentang Penguatan Sistem Inovasi Daerah (Berita Negara Republik Indonesia Tahun 2012 
Nomor 484); Peraturan Menteri Pendayagunaan Aparatur Negara Dan Reformasi Birokrasi Republik Indonesia Nomor 30 Tahun 2014 Tentang Pedoman Inovasi Pelayanan Publik; Peraturan Menteri Dalam Negeri Nomor 80 Tahun 2015 tentang Pembentukan Produk Hukum Daerah (Berita Negara Republik Indonesia Tahun 2015 Nomor 2036); Peraturan Menteri Dalam Negeri Nomor 86 Tahun 2017 tentang Tata Cara Perencanaan, Pengendalian dan Evaluasi Pembangunan Daerah, Tata Cara Evaluasi Rancangan Peraturan Daerah tentang Rencana Pembangunan Jangka Panjang Daerah dan Rencana Pembangunan Jangka Menengah Daerah serta Tata Cara Perubahan Rencana Pembangunan Jangka Panjang Daerah, Rencana Pembangunan Jangka Menengah Daerah, dan Rencana Kerja Pemerintah Daerah (Berita Negara Republik Indonesia Tahun 2017 Nomor 1312); Peraturan Menteri Pendayagunaan Aparatur Negara Dan Reformasi Birokrasi Republik Indonesia Nomor 3 Tahun 2018 Tentang Kompetisi Inovasi Pelayanan Publik Di Lingkungan Kementerian/Lembaga, Pemerintah Daerah, Badan Usaha Milik Negara, Dan Badan Usaha Milik Daerah Tahun 2018; Peraturan Menteri Dalam Negeri Republik Indonesia Nomor 3 Tahun 2018 Tentang Penerbitan Surat Keterangan Penelitian; Peraturan Daerah Kabupaten Bekasi Nomor 3 Tahun 2010 Tentang Rencana Pembangunan Jangka Panjang Daerah (RPJPD) Kabupaten Bekasi Tahun 2005-2025; Peraturan Daerah Kabupaten Bekasi Nomor 7 Tahun 2017 tentang Rencana Pembangunan Jangka Menengah Kabupaten Bekasi tahun 2017-2022.

Road map Sistem Inovasi Daerah (SIDa) Kabupaten Bekasi sangat penting sebagai sistem yang mengatur dan mengarahkan untuk terbentuknya kondisi lingkungan yang kondusif dan harmonis dalam mendorong terciptanya tumbuh kembang inovasi serta teknologi baru yang bermanfaat dalam meningkatkan efisiensi proses suatu produk baik berupa barang maupun jasa. Melalui dokumen Road Map SIDa, diharapkan potensi-potensi lokal di Kabupaten Bekasi dapat diidentifikasi untuk selanjutnya, dengan memperhatikan arah pembangunan yang telah direncanakan pada level pemerintahan yang lebih atas, potensi-potensi tersebut dapat dikembangkan secara inovatif untuk memperoleh outcome yang optimal.

Berdasarkan uraian di atas fokus dari kegiatan Penyusunan Laporan Road map Sistem Inovasi Daerah (SIDa) Kabupaten Bekasi mencakup beberapa hal sebagai berikut: Pertama, sinergi dalam pelaksanaan pembangunan pemerintah Kabupaten Bekasi dengan kebijakan pemerintah pusat dan kebijakan pemerintah daerah, melalui inovasi tata kelola Pemerintahan Daerah dan inovasi Pelayanan Publik serta Inovasi Daerah lainnya sesuai dengan Urusan Pemerintahan yang menjadi kewenangan Daerah Kabupaten Bekasi. Kedua, terkait kontruksi jejaring inovasi daerah kabupaten bekasi yang diperkuat melalui jejaring pemerintah, perguruan tinggi, dunia usaha, masyarakat, dan media. Ketiga, sebagai petunjuk atau arahan bagi para pihak terkait dalam pengembangan sistem inovasi untuk meningkatkan daya saing daerah Kabupaten Bekasi di era pembangunan yang semakin kompetitif. Keempat pedoman dalam penyusunan Rencana Kerja Organisasi Perangkat Daerah atau Pemerintah Daerah Kabupaten Bekasi. 
METODE PENELITIAN

Metode penelitian yang digunakan adalah metode penelitian kualitatif dengan cara memetakan data-data sekunder dengan melihat kekuatan, kelemahan, peluang, dan ancaman mencipatakan inovasi di Kota Bekasi.

\section{HASIL DAN PEMBAHASAN}

Sistem inovasi merupakan suatu kesatuan komponen yang mempengaruhi arah perkembangan dan kecepatan inovasi, difusi, dan proses pembelajaran dalam pengembangan, penguasaan, pemajuan dan penerapan/ pemanfaatan iptek. Bagaimana subsubsistem (elemen/ faktor) berperan, kesaling-terkaitannya (termasuk koherensi kebijakannya), dan dinamika interaksinya menentukan atau mempengaruhi kinerja dinamis sistem inovasi. Penguatan sistem inovasi berarti membenahi sistem (holistik, serentak, isu-isu sistemik) secara terstruktur. Dalam perspektif kebijakan, penguatan sistem inovasi berarti langkah perbaikan yang perlu diarahkan untuk membenahi isu-isu kegagalan sistemik (systemic failures). Oleh karena itu, strategi kebijakan perlu dikembangkan sebagai suatu kesatuan kerangka kebijakan inovasi (KKI) untuk memperkuat sistem (Taufik, 2012 dalam Kuncoro B. Prayitno dkk. 2014:73).

Menurut Peraturan Bersama Menteri Negara Riset Dan Tekonologi Republik Indonesia dan Menteri Dalam Negeri Republik Indonesia Nomor 03 Tahun 2012 dan Nomor 36 Tahun 2012 Tentang Penguatan Sistem Inovasi Daerah, pada Pasal 1 ayat 2 berbunyi Sistem Inovasi Daerah yang selanjutnya disingkat SIDa bahwa: "keseluruhan proses dalam satu sistem untuk menumbuhkembangkan inovasi yang dilakukan antar institusi pemerintah, pemerintah daerah, lembaga kelitbangan, lembaga pendidikan, lembaga penunjang inovasi, dunia usaha, dan masyarakat di daerah."

Di dalam pasal 4 Peraturan Pemerintah Republik Indonesia Nomor 38 Tahun 2017 Tentang Inovasi Daerah, disebutkan bahwa bentuk inovasi daerah mencakup a. inovasi tata kelola Pemerintahan Daerah; dan b. inovasi Pelayanan Publik; dan/atau Inovasi Daerah lainnya sesuai dengan urusan pemerintahan yang menjadi kewenangan daerah. Inovasi Daerah lainnya sebagaimana dimaksud tersebut merupakan segala bentuk inovasi dalam penyelenggaraan urusan pemerintahan yang menjadi kewenangan Pemerintah Daerah.

Urgensi sistem inovasi daerah diperkuat melalui berbagai instrumen kebijakan pemerintah. Berbagai Peraturan perundang-undangan ditetapkan untuk selanjutnya dapat terimplementasi dalam pembangunan di daerah. Salah satu Peraturan Presiden yang dikeluarkan secara khusus terkait inovasi daerah adalah Peraturan Pemerintah Republik Indonesia Nomor 38 Tahun 2017 Tentang Inovasi Daerah (Tambahan Lembaran Negara Republik Indonesia Nomor 6123). Hal ini sangat beralasan karena dalam tata kelola pemerintahan di era otonomi daerah sudah disebutkan dalam Undang-undang diantaranya Undang-Undang Republik Indonesia Nomor 18 Tahun 2002 tentang Sistem Nasional Penelitian, Pengembangan, dan Penerapan Ilmu Pengetahuan dan Teknologi (Tambahan Lembaran Negara Republik Indonesia Nomor 4219); serta dalam Undang-undang Nomor 23 Tahun 2014 tentang Pemerintahan Daerah (Lembaran Negara Republik Indonesia Tahun 2014 Nomor 244); 
Roadmap Sistem Inovasi Daerah (SIDa) Kabupaten Bekasi sangat penting sebagai sistem yang mengatur dan mengarahkan untuk terbentuknya kondisi lingkungan yang kondusif dan harmonis dalam mendorong terciptanya tumbuh kembang inovasi serta teknologi baru yang bermanfaat dalam meningkatkan efisiensi proses suatu produk baik berupa barang maupun jasa. Melalui dokumen Road Map SIDa, diharapkan potensi-potensi lokal di Kabupaten Bekasi dapat diidentifikasi untuk selanjutnya, dengan memperhatikan arah pembangunan yang telah direncanakan pada level pemerintahan yang lebih atas, potensi-potensi tersebut dapat dikembangkan secara inovatif untuk memperoleh outcome yang optimal.

Berdasarkan uraian di atas fokus dari kegiatan Penyusunan Laporan Roadmap Sistem Inovasi Daerah (SIDa) Kabupaten Bekasi mencakup beberapa hal sebagai berikut : Pertama, sinergi dalam pelaksanaan pembangunan pemerintah Kabupaten Bekasi dengan kebijakan pemerintah pusat dan kebijakan pemerintah daerah, melalui inovasi tata kelola Pemerintahan Daerah dan inovasi Pelayanan Publik serta Inovasi Daerah lainnya sesuai dengan Urusan Pemerintahan yang menjadi kewenangan Daerah Kabupaten Bekasi. Kedua, terkait kontruksi jejaring inovasi daerah kabupaten bekasi yang diperkuat melalui jejaring pemerintah, perguruan tinggi, dunia usaha, masyarakat, dan media. Ketiga, sebagai petunjuk atau arahan bagi para pihak terkait dalam pengembangan sistem inovasi untuk meningkatkan daya saing daerah Kabupaten Bekasi di era pembangunan yang semakin kompetitif. Keempat pedoman dalam penyusunan Rencana Kerja Organisasi Perangkat Daerah atau Pemerintah Daerah Kabupaten Bekasi.

Kondisi capaian pembangunan di Kabupaten Bekasi dewasa ini dapat dikatakan masih cenderung ditentukan oleh besaran faktor-faktor ekonomi yang menggerakkan proses pembangunan. Maka, guna meningkatkan daya ungkit bagi peningkatan kesejahteraan yang lebih baik, perlu dilakukan upaya transformasi secara sistemik melalui kerangka Sistem Inovasi Daerah (SIDa) diharapkan dapat mencapai target sasaran pembangunan di Kabupaten Bekasi, hal ini diharapkan mampu menggerakkan seluruh proses yang semakin efisien dengan mendayagunakan IPTEK. Pada posisi tersebut, faktor inovasi menjadi kata kunci baru dalam mewujudkan peningkatan efisiensi dan kualitas hasil dari proses pembangunan. Dengan memperhatikan kebutuhan transformasi dalam pembangunan di Kabupaten Bekasi di atas, perlu penyusunan Road Map Sistem Inovasi Daerah (SIDa). Road Map SIDa Kabupaten Bekasi Tahun 2017-2022 perlu memiliki skema pentahapan penciptaan kondisi inovasi sebagai penggerak proses pembangunan daerah. Pemerintah Daerah Kabupaten Bekasi harus senantiasa bersinergi memperkuat penataan unsur inovasi daerahnya, dalam upaya pencapaian target sasaran pembangunan yang diamanatkan dalam RPJMD Kabupaten Bekasi Tahun 2017-2022.

\begin{tabular}{lcr}
\multicolumn{2}{c}{ Kabupaten } & Bekasi \\
membutuhkan & beberapa & paket \\
kebijakan berkaitan & dengan \\
peningkatan & daya & saing \\
pembangunan daerah & melalui \\
penguatan sistem inovasi. & Target \\
capaian kondisi innovation-driven
\end{tabular}


development pada tahun 2023 perlu diwujudkan melalui tiga tahap (stage). Berikut dideskripsikan berbagai kondisi strategis yang diharapkan terwujud dalam tiga tahapan pelaksanaan Sistem Inovasi Daerah (SIDa) Kabupaten Bekasi.

Terciptanya Daya Dukung SIDa di Kabupaten Bekasi (2019-2023)

Untuk meningkatkan kerangka dasar (pondasi) SIDa di Kabupaten Bekasi diperlukan kebijakan penguatan daya dukung inovasi. Sistem inovasi pada dasarnya merupakan suatu kesatuan yang terdiri dari berbagai stakeholders, kelembagaan, jaringan, kemitraan, hubungan interaksi dan proses produktif yang mempengaruhi arah perkembangan, kecepatan inovasi dan proses pembelajaran berbasis masyarakat (society) yaitu masyarakat perkotaan dan perdesaan. Penguatan daya dukung SIDa perlu diarahkan kepada proses pengembangan IPTEK pada berbagai basis produksi unggulan dalam masyarakat perdesaan. Transformasi basis produksi unggulan perlu diarahkan menuju terwujudnya kapasitas daya dukung kelembagaan, jejaring dan sumber daya yang handal. Kebijakan penguatan daya dukung sistem inovasi merupakan wahana utama untuk meningkatkan pondasi SIDa dan kohesi sosial dalam mewujudkan masyarakat yang semakin sejahtera, mandiri dan beradab menuju penciptaan kondisi innovation-driven development. Untuk Mewujudkan Kabupaten Bekasi yang lebih Maju, Sejahtera, dan Berkeadilan yang berbasis innovation-driven development pada 2023, diperlukan beberapa langkahlangkah penguatan terhadap tahap awal (pertama) penciptaan daya dukung SIDa.

\section{Pembentukan Kerangka Jejaring Inovasi}

Tahap awal penataan unsur jejaring yang perlu dicapai dalam mendukung penciptaan daya dukung SIDa adalah menumbuhkembangkan berbagai kolaborasi atau kerjasama dalam proses inovasi dan difusi IPTEK (praktek baik/terbaik dan/atau hasil riset). Tujuan utamanya ialah merintis terciptanya interaksi produktif multi pihak yang saling menguntungkan bagi perkembangan inovasi dan difusinya, penyebarluasan praktek baik dan hasil-hasil riset yang sesuai dengan potensi terbaik di lingkup Kabupaten Bekasi. Guna menciptakan kerangka sistemik dalam pengembangan kerangka jejaring SIDa, maka perlu didorong melalui agenda pengembangan penyelenggaraan pemerintahan Kabupaten Bekasi secara inovatif. Pengembangan iklim yang kondusif bagi proses- proses inovasi dapat dilaksanakan melalui SKPD (Satuan Kerja Perangkat Daerah) secara inovatif. Kemajuan SIDa di suatu daerah akan ditentukan oleh seberapa cepat dan kuatnya pondasi jejaring inovasi yang dapat didorong oleh pemerintah kabupaten/kota yang bersangkutan.

\section{Pembentukan Kerangka Kelemba- gaan Inovasi}

Tahap (milestones) awal yang hendak dicapai dalam penataan unsur kelembagaan guna mendukung penciptaan daya dukung SIDa adalah penguatan unsur-unsur kelembagaan guna mendukung penciptaan kerangka umum yang kondusif bagi inovasi. Arah pengembangan kelembagaan pada pada tahap awal ini intinya berkaitan dengan tujuan menciptakan iklim daerah yang kondusif, khususnya bagi aktivitas pemerintahan, aktivitas ekonomi masyarakat perdesaan dan dunia usaha. Perwujudan pondasi sistem 
inovasi daerah (SIDa) dilakukan melalui penataan potensi dan daya dukung berbagai unsur organisasi, kerangka regulasi dan internalisasi budaya inovasi. Tahap pertama penataan kerangka kelembagaan SIDa terkait pula dengan upaya pengenalan budaya inovasi dalam berbagai organisasi/lembaga inovasi daerah. Tujuan agenda itu ialah membangun landasan budaya kreatifinovatif masyarakat. Penataan daya dukung kelembagan IPTEK/kelitbangan perlu ditopang melalui agenda pemetaan potensi unggulan desa-desa di Kabupaten Bekasi untuk dikembangkan secara inovatif. Maka dalam tataran pengembangan kelembagan perlu dibangun kerangka model pengembangan desa inovasi sebagai strategi pengembangan basis kelembagaan SIDa yang terarah, terintegrasi, sistematis dan berkelanjutan.

\section{Pembangunan \\ Kerangka Penguatan Sumber Daya Inovasi}

Penataan kerangka penguatan sumber daya sangat strategis dalam upaya mempersiapkan masyarakat memasuki era ekonomi pengetahuan (knowledge economy) dan masyarakat pengetahuan (knowledge society). Arah pengembangan sumber daya SIDa perlu diwujudkan melalui peningkatan kesadaran berbagai pihak terhadap aspek strategis IPTEK bagi pengembangan kegiatan ekonomi dan sektor-sektor pembangunan lainnya. Tahap awal penataan kerangka sumber daya perlu dilakukan melalui upaya menumbuhkembangkan dan memperkuat keterpaduan peningkatan sumber daya di Kabupaten Bekasi. Tujuan utamanya ialah mendorong aktivitas inovasi semua masyarakat Kabupaten Bekasi untuk saling bersinergi, meningkatkan pengetahuan, keterampilan dan mulai memahami perkembangan global untuk dimanfaatkan bagi kepentingan daerah. Tujuan utamanya adalah terjadinya penguatan rantai nilai pengembangan sektor unggulan berbasis teknologi di Kabupaten Bekasi. Lebih lanjut perlu mulai membentuk jiwa kewirausahaan (entrepreneur) masyarakat agar mampu mengelola berbagai kegiatan inovasi menuju pada pembentukan keuntungan ekonomi.

Pemantapan Kapasitas SIDa di Kabupaten Bekasi (2019-2020)

Tahapan kedua merupakan tahap lanjut dari proses Pembangunan Daya Dukung (pondasi) SIDa adalah tercapainya kapasitas inovasi dari berbagai kelembagaan SIDa. Hal tersebut akan terlihat dari semakin luasnya wilayah pengembangan dan dihasilkannya peningkatan besaran produksi berbagai usaha masyarakat dan perluasan bidang-bidang baru yang mampu dikembangkan secara inovatif baik pada organisasi pemerintahan, masyarakat, maupun dunia usaha.

\section{Penguatan Kapasitas Kelembagaan Inovasi}

Tahap kedua yang hendak dicapai dalam penataan unsur kelembagaan guna mendukung pemantapan kapasitas SIDa adalah semakin kuatnya elemen kelembagaan yang mendukung penciptaan kerangka umum bagi inovasi daerah. Arah pengembangan kelembagaan pada tahap kedua ini intinya berkaitan dengan tujuan menciptakan iklim daerah yang semakin kondusif, khususnya bagi aktivitas pemerintahan, ekonomi masyarakat perdesaan dan dunia usaha. Perwujudan pemantapan kapasitas SIDa dilakukan melalui pemantapan daya dukung berbagai unsur organisasi, kerangka regulasi 
dan internalisasi budaya lokal. Penataan kapasitas kelembagaan IPTEK/kelitbangan perlu ditopang melalui pengembangan berbagai potensi unggulan daerah di Kabupaten Bekasi. Maka target capaian dalam tataran pengembangan daerah inovasi adalah semakin kuatnya kelembagaan proses inovasi produktif di Kabupaten Bekasi. Tahap kedua penataan kerangka kelembagaan SIDa terkait pula dengan upaya pemantapan budaya inovasi dalam berbagai organisasi/lembaga inovasi daerah. Tujuan agenda itu ialah mulai mantapnya landasan budaya kreatifinovatif dan kohesi sosial ekonomi berbasis masyarakat.

\section{Penguatan Kapasitas Jejaring Inovasi}

Pada tahap ini unsur jejaring yang perlu dicapai dalam mendukung pemantapan kapasitas SIDa adalah semakin banyaknya kolaborasi atau kerjasama dalam proses inovasi dan difusi IPTEK (praktek baik/terbaik dan/atau hasil riset). Tujuan utamanya ialah tercapainya interaksi intensif dan produktif multipihak yang saling menguntungkan bagi perkembangan inovasi dan difusinya, penyebarluasan praktek baik dan hasil-hasil litbang yang sesuai dengan potensi terbaik di lingkup Kabupaten Bekasi. Guna menciptakan kerangka sistemik dalam pengembangan kerangka jejaring SIDa, maka agenda Pengembangan Inovatif di Kabupaten Bekasi perlu memiliki target pengembangan yang lebih luas. Pengembangan iklim inovasi yang semakin kondusif yang diwujudkan melalui semakin mantapnya dukungan penyelenggaraan unsurunsur pemerintahan daerah dalam berbagai proses inovatif. Pengembangan kapasitas SIDa di suatu daerah ditentukan oleh riilnya dukungan pemerintahan daerah melakukan pengembangan jejaring inovasi sebagai proses yang produktif dan mampu meningkatakan kesejahteraan masyarakat.

\section{Penguatan Kapasitas Sumber Daya Inovasi}

Arah pengembangan sumber daya SIDa pada tahap kedua perlu diwujudkan melalui peningkatan kesadaran dan perhatian nyata berbagai pihak terhadap aspek strategis IPTEK bagi pengembangan kegiatan ekonomi dan bidang-bidang pembangunan lainnya. Pemantapan kapasitas sumber daya SIDa perlu diwujudkan melalui upaya pemantapan berbagai proses inovatif dan memperkuat keterpaduan peningkatan sumber daya yang di Kabupaten Bekasi. Tujuan utamanya ialah mendorong aktivitas inovasi di semua sektor yang semakin bersinergi, mampu meningkatkan pengetahuan, keterampilan dan semakin dapat memahami dan menguasai perkembangan global untuk dimanfaatkan bagi kepentingan daerah. Tujuan utamanya adalah terjadinya penguatan kapasitas pengembangan sektor-sektor unggulan daerah berbasis teknologi di Kabupaten Bekasi. Lebih lanjut perlu memantapkan jiwa kewirausahaan (entrepreneur) masyarakat agar mampu mengelola berbagai kegiatan inovasi menuju pada kemandirian.

Terwujudnya Daya Saing SIDa di Kabupaten Bekasi (2019-2023)

Pada tahap ketiga merupakan lanjutan dari proses pemantapan kapasitas SIDa pada tahap sebelumnya. Arah pengembangannya adalah tercapainya produktivitas dan daya saing berbagai inovasi yang dikembangkan sesuai dengan action plan. Pada tahap akhir periode ini diharapkan tercapainya beberapa indikator Pembangunan daerah yang 
berkaitan dengan pengembangan inovasi.

\section{Penciptaan Daya Saing Unsur Kelembagaan}

Inovasi Tahapan ketiga yang hendak dicapai dalam penataan unsur kelembagaan guna mendukung perwujudan daya saing SIDa adalah semakin kuatnya unsur-unsur kelembagaan guna mendukung penciptaan kerangka umum yang semakin kondusif bagi inovasi. Arah pengembangan kelembagaan pada tahap ketiga ini berkaitan dengan tujuan menciptakan iklim daerah yang semakin kondusif bagi aktivitas pemerintahan, ekonomi masyarakat perdesaan dan dunia usaha. Perwujudan daya saing Sistem Inovasi Daerah (SIDa) dilakukan melalui pemantapan kapasitas organisasi, kerangka regulasi dan internalisasi budaya inovasi. Daya saing kelembagaan IPTEK/riset perlu ditopang melalui pengembangan desadesa inovasi di Kabupaten Bekasi, maka target yang akan dicapai adalah terciptanya efisiensi kelembagaan proses inovasi produktif di perdesaan Kabupaten Bekasi.

Tahapan ketiga penataan kerangka kelembagaan SIDa terkait pula dengan upaya pemantapan budaya inovasi dalam berbagai organisasi/lembaga inovasi daerah. Tujuan yang akan dicapai adalah terbangunnya dan berkembangnya landasan budaya kreatifinovatif, kewirausahaan dan kohesi sosial masyarakat Kabupaten Bekasi.

\section{Penciptaan Daya Saing Jejaring Inovasi}

Tahapan ketiga unsur jejaring yang perlu dicapai dalam mendukung perwujudan daya saing SIDa di Kabupaten Bekasi adalah semakin meratanya kolaborasi atau kerjasama dalam proses inovasi dan difusi IPTEK (praktek baik/terbaik dan/atau hasil riset). Tujuan utamanya ialah tercapainya interaksi yang intensif dan produktif multipihak yang saling menguntungkan bagi perkembangan inovasi dan difusinya, penyebarluasan praktek baik dan hasil-hasil riset yang sesuai dengan potensi terbaik di lingkup Kabupaten Bekasi. Kerangka sistemik dalam pengembangan kerangka jejaring SIDa, maka agenda pengembangan inovatif di Kabupaten Bekasi perlu memiliki target pengembangan kualitas daya saing. Pengembangan iklim inovasi yang kondusif dapat diwujudkan secara nyata dan mendapat dukungan stakeholders dan SKPD dalam berbagai proses inovatif di Kabupaten Bekasi. Indikator pencapaian target pada tahap ini adalah: meningkatnya dukungan pemerintahan daerah dalam pengembangan jejaring inovasi sebagai proses yang produktif dan mampu meningkatkan kesejahteraan masyarakat.

\section{Penciptaan Daya Saing Sumber Daya Inovasi}

Arah pengembangan sumber daya SIDa pada tahap ketiga perlu diwujudkan melalui pemantapan kesadaran dan perhatian nyata berbagai pihak terhadap aspek strategis IPTEK bagi pengembangan sektor ekonomi dan lainnya. Daya saing sumber daya SIDa perlu diwujudkan melalui upaya pemantapan berbagai proses inovatif dan sinergisitas pemanfaatan sumber daya masyarakat di Kabupaten Bekasi. Tujuan utamanya ialah mendorong aktivitas inovasi yang berkualitas, bersinergi, terintegrasi dan terbentuknya peningkatan daya saing pengembangan daerah berbasis teknologi di Kabupaten Bekasi dalam rangka pencapaian VISI dan MISI RPJMD Kabupaten Bekasi periode 2019-2023. 
Perumusan

program

pembangunan daerah menghasilkan rencana pembangunan yang konkrit dalam bentuk program prioritas yang secara khusus berhubungan dengan capaian sasaran pembangunan daerah. Dalam mewujudkan capaian keberhasilan pembangunan, Pemerintah Kabupaten Bekasi menetapkan rangkaian program sesuai dengan urusan pemerintahan wajib dan urusan pemerintahan pilihan yang dilaksanakan oleh Perangkat Daerah di lingkungan Pemerintah Kabupaten Bekasi. Penetapan program pembangunan dan penanganan urusan pembangunan yang disesuaikan dengan misi pembangunan daerah adalah sebagai berikut:

1. Meningkatkan kinerja tata kelola pemerintahan yang responsif, profesional, transparan dan akuntabel

2. Memantapkan pembangunan sumber daya manusia yang berkualitas

3. Memantapkan perekonomian daerah melalui penguatan sektor pertanian, perindustrian, perdagangan, dan pariwisata

4. Meningkatkan pemberdayaan ekonomi masyarakat melalui pengembangan usaha mikro, kecil, menengah dan koperasi (UMKM)

5. Meningkatkan Kualitas Hidup Masyarakat melalui Pemantapan Penyediaan Kebutuhan Dasar yang Layak

6. Mewujudkan Kabupaten Bekasi yang Lebih Nyaman dan Asri melalui Penataan Ruang dan Pembangunan Infrastruktur yang Terpadu

7. Mewujudkan lingkungan masyarakat yang Agamis dan Tentram melalui pengembangan nilai-nilai budaya local

8. Mewujudkan pengelolaan sumber daya alam dan lingkungan hidup yang berkelanjutan

\section{KESIMPULAN}

Perwujudan visi dan misi daerah merupakan salah satu bentuk konkrit pembangunan daerah Kabupaten Bekasi, untuk itu perlu dirumuskan kebijakan penguatan SIDa Kabupaten Bekasi yang memiliki strategi dan arah kebijakan. Strategi merupakan langkah yang dilakukan dalam mencapai tujuan dan sasaran pembangunan inovasi daerah, sedangkan arah kebijakan merupakan pedoman untuk mengarahkan rumusan strategis yang dipilih agar lebih terarah dalam mencapai tujuan dan sasaran SIDa. Rumusan arah kebijakan merasionalkan pilihan-pilihan strategis agar memiliki fokus dan sesuai dengan pengaturan pelaksanaannya.

Sistem inovasi daerah (SIDa) diangkat dan dibahas dalam Peraturan Bersama Kementerian Dalam Negeri Republik Indonesia No. 3 tahun 2012 dan Kementerian Riset dan Teknologi No. 36 tahun 2012 tentang Penguatan Sistem Inovasi Daerah dan juga selaras dengan Undang-Undang No. 18 tahun 2002 tentang Sistem Nasional Penelitian, Pengembangan, dan Penerapan IPTEK, serta Peraturan Pemerintah Republik Indonesia Nomor 38 Tahun 2017 Tentang Inovasi Daerah. Selain itu secara aplikatif pun dipertajam melalui UU No. 23 tahun 2014 tentang Pemerintahan Daerah bahwa perlu adanya inovasi dari pemerintah daerah untuk meningkatkan kinerja pemerintahan. Kemudian pada tahun 2014 Menteri Pendayagunaan Aparatur Negara Dan Reformasi Birokrasi Republik Indonesia Nomor 30 Hun 2014 Tentang Pedoman Inovasi Pelayanan Publik. Upaya pemerintah dalam mendukung inovasi daerah diperkuat dengan Peraturan Menteri Dalam Negeri Republik Indonesia Nomor 104 
Tahun 2018 Tentang Penilaian Dan Pemberian Penghargaan Dan/Atau Insentif Inovasi Daerah.

Di dalam pasal 4 Berdasarkan Peraturan Pemerintah Republik Indonesia Nomor 38 Tahun 2017 Tentang Inovasi Daerah, disebutkan bahwa bentuk inovasi daerah mencakup a. inovasi tata kelola Pemerintahan Daerah; dan b. inovasi Pelayanan Publik; dan/atau Inovasi Daerah lainnya sesuai dengan Urusan Pemerintahan yang menjadi kewenangan Daerah. Inovasi Daerah lainnya sebagaimana dimaksud tersebut merupakan segala bentuk inovasi dalam penyelenggaraan Urusan Pemerintahan yang menjadi kewenangan Pemerintah Daerah. Dengan demikian, potensi inovasi daerah dalam Sistem Inovasi Daerah (SIDa) Kabupaten Bekasi berkaitan dengan urusan pemerintahan yang telah menjadi kewenangan daerah otonom, asset daerah, potensi daerah, penelitian dan pengembangan, ilmu pengetahuan dan teknologi serta penyediaan pelayanan publik.

\section{REFERENSI}

Alwi, Hasan. 2005. Kamus Besar Bahasa Indonesia, Edisi III. Jakarta: Balai Pustaka

Bengt-Åke Lundvall. 1992. "National Systems of Innovation. Towards a Theory of Innovation and Interactive Learning". London: Pinter Publishers.

Etzkowitz, H., \& Leydesdorff, L. 1995. The Triple Helix-UniversityIndustry-Government Relations: A Laboratory for KnowledgeBased Economic Development. EASST Review.
Kuncoro B. Prayitno dkk. 2014. Kebijakan Inovasi Di Industri. Jakarta: BPPT Press.

Kuncoro, 2004. Mudrajad, Otonomi dan Pembangunan Daerah, Reformasi, Perencanaan, Strategi dan Peluang, Erlangga

Nuryulia Praswati, Aflit. 2017. Perkembangan Model Helix Dalam Peningkatan Inovasi. Sukoharjo:,Fakultas Ekonomi dan Bisnis Universitas Muhammadiyah Surakarta, Jl. A. Yani Tromol Pos Pabelan Kartasura.

Pitts, Robert A, \& David Lei, 1996. Strategic Management, Building and Sustaining Competitive Advantage, West Publishing Company, St Paul,

Pratikno, et.al. 2004. Mengelola Dinamika Politik dan Sumberdaya Daerah, Yogyakarta: PLOD Departemen Dalam Neger London: Sage Publications, International Educational and Professional

Rosen, E.D. 1993. Improving Public Sector Productivity: Concept and Practice.

Tarigan, Antonius. 2009. Meningkatkan Daya Saing Wilayah. Buletin Tata Ruang, Maret-April

Widjajani, Arnia Fajarwati, Asep Hidayat. 2017. Model Quadruple Helix Sebagai Model Inovasi Daerah (Kajian Literatur) Bandung: Universitas Langlangbuana Bandung. 